\title{
An Empirical Study about Customer Preferences of Retail Sellers' Qualifications
}

\author{
Najah Hassan Salamah ${ }^{1}$ \\ ${ }^{1}$ Assistant Professor, Department of Marketing, Faculty of Economic and Administration, King Abdul-Aziz \\ University, Saudi Arabia \\ Correspondence: Najah Hassan Salamah, Assistant Professor, Department of Marketing, Faculty of Economic \\ and Administration, King Abdul-Aziz University, Saudi Arabia. E-mail: nsalamah@kau.edu.sa
}

Received: January 10, 2017

Accepted: February 16, 2017

Online Published: February 17, 2017

doi:10.5539/ibr.v10n3p193

URL: https://doi.org/10.5539/ibr.v10n3p193

\begin{abstract}
The purpose behind the study was to analyze the skills and behaviors required by Saudi retail sellers in developing interest of the consumers towards purchasing from retail stores. The sample size of 384 participants has been considered for data collection. Descriptive statistics and frequencies have been used to generate and analyze the data. Results have indicated that majority of respondents embarked on retail shops with Saudi sales men, because they were characterized by truthfulness, honesty, and patience. Moreover, approximately $96.10 \%$ of respondents gave preference to the retail shops, which were managed by properly trained Saudi seller. It has been observed that it is important to consider that Saudi seller should possess the qualities of patience, faithfulness, seriousness in work, while recruiting, and appointing them. The importance of qualities, which should be possessed by seller, has been highlighted through outcomes. Moreover, the emphasis is given to provide training to the seller for enhancing their selling skills and capabilities.
\end{abstract}

Keywords: customer preferences, personal selling, retail shops, seller

\section{Introduction}

Personal selling has become one of the most important trends in administrative thinking. These trends have been represented in most prominent challenges that confront the organizations today, specifically in retail selling domain. Retail selling concept has been presented in the framework, which helped to identify the concepts and intellectual philosophies. These concepts are derived by focusing on the individual shopping. Personal selling mechanism has been determined as beneficial for a salesperson, as it enables to customize marketing message to the customers (Kumanduri et al., 2014). The study of contemporary personal selling, especially in Saudi society, has become an urgent necessity. The human element is considered as one of the most vital resources that are possessed by an organization. The value of these resources can be increased by investing in the promotion of capabilities of personnel as well as securing due incentives for such personnel.

\subsection{Problem}

The principles, which are necessarily required by Saudi selling persons with respect to personal selling have not been focused by previous investigations, particularly in Saudi Arabia. Due to the lack of exploration concerning the experiences of consumers in their shopping and role of sales men on the consumer purchasing behaviour, present study has aimed to observe the seller competencies along with the trends of Saudi consumers. Within the framework of numerous cultural and social changes, the pressures on Saudi seller increase tremendously. This aspect gave rise to the following question:

1) How the behavior of Saudi seller influences the consumer's interest to purchase from retail shops?

2) How the consumer behaviour is attracted towards the seller competencies, which enables them to purchase from retail shops?

3) Does Saudi sales men possess the qualities of competent sales man?

\subsection{Significance}

The study has contributed in the domain of buying and selling, and recognized some specific results. The study significantly identified the consumer perceptions about sales men's sincerity and the behaviour of interaction. 
The skills of Saudi sales men while dealing with the customers have been significantly observed and the requirement of providing further training to the sales men in Jeddah has been highlighted. The strengths and weaknesses regarding skills of sales men in attracting consumers to buy certain product or service have been examined to identify the qualifications or experiences of sales men, particularly in Jeddah, Saudi Arabia.

\subsection{Objectives}

The study has developed certain objectives, which are as follow:

- To study the strengths of Saudi seller in assisting the consumer's purchasing decision.

- To recognize the importance of practical qualities that Saudi seller should possess.

- To assure the extent to which the Saudi sellers possess required qualities and their impact on consumer's interests to purchase from retail shops.

- To submit a set of recommendations on personal selling in a manner that suits the nature of Saudi market.

\section{Literature Review}

In order to engage in selling a product efficiently; the sales man has to play different roles to involve in various activities, and to use distinctive set of knowledge, skills, and abilities. For practicing an efficient selling, a complex structure of knowledge and the ability to effectively utilize knowledge are necessarily required by a sales person. An efficient sales person should possess more knowledge about its customers as compared to any other professional. Moreover, a sales man should be comprised of interpersonal, mentalizing, and emotional intelligence qualities. In interpersonal metalizing, the sales man is required to consider the mental states and intentions of customers towards purchasing (Dietvorst et al., 2009). Emotional intelligence is an important aspect of psychology, which is related with personal selling. Hence, a salesman with high emotional intelligence can efficiently perceive and manage the emotions of its customers (Lilien and Grewal, 2012).

In respect of relationship significance among customers and personal selling, it has been examined that many companies have given this activity a great importance to reach the best level of performance. This significance not only leads to enhance the sales, but also reflects a positive image of companies in their respective communities. For a long-term success, companies generally consider customer satisfaction as a unique element. The long-term association between the company and consumers is important as it is beneficial for both parties (Pettijohn et al., 2002).

Culture also evaluates the way through which consumers respond to brand images, prices, and advertising components (Shavitt and Cho, 2016). The knowledge about consumers' behavior is of great importance, as it enables the salesperson to understand how consumers feel, think, and select from alternatives, while purchasing a product or brand. Taking into consideration the behavior of Saudi consumers, it has been proposed by Rahman (2012) that the retail market of Saudi Arabia is not an exception. Within the retail markets, changing scenario of consumer behavior in Saudi Arabia provides a proof to the availability of potential opportunities. In order to identify the consumer behavior regarding purchasing decision, companies usually conduct detailed surveys to evaluate the requirements of consumers. Some of the factors, which show an influence on consumer buying behavior include social, psychological, and personal factors (Kotler et al., 2015).

The roles of service quality satisfaction and perception in the origination of behavioural intentions have been recognized by the services marketing literature. The intervening role of satisfaction in regards with the relationship between behavioural intentions and service quality have been established. A study conducted by Bijmolt et al. (2014) on online purchasing behaviour explored that there are remarkable differences regarding intentions to repurchase a particular product among the consumers. Consumers, who complained because of negative experiences, expressed higher intentions to repurchase a particular product or service than the consumers with no negative experience. This study was one of the significant empirical studies concerning the situations of complaints and dissatisfaction related to online purchase behaviour.

Another study by Ozer \& Gultekin, (2015) has intended to explore the influence of pre-purchase behaviour and desire to buy a certain product. The effect of impulse buying behaviour on post-mood has also been considered. The results examined the pre and post-purchase mood effects with consumer satisfaction as a mediating variable. The tendency of consumer's impulse pre-purchase mood encourage impulse buying positively. It has also been observed that impulse buying has no effects on the purchasing mood of the consumers, and consumer's satisfaction has a partial mediator role between the pre and post-purchasing mood.

The ethical behavior of sales men has also a significant influence on the commitment and relationship of 
customers. This is because honest actions of salesman results in increasing the trust of customers on salesman, and also on the organization. In this way, customer loyalty towards the product also increases. It has been evaluated that a strong relationship exists among ethical sales behavior of salesman, customer satisfaction, and customer loyalty. Thus, the ethical behavior of salesman plays a fundamental role in retaining the customer loyalty (Lin, 2012). Moreover, it has been determined that seller plays an important role in maintaining the existence of the store via achieving the satisfaction, confidence and loyalty of customers. The findings of the study conducted by Tolba et al. (2015) have shown positive relationship between the store and consumer resulting from good interaction, which has been established by seller with its targeted customers.

The salesperson intelligence is often utilized by organizations in marketing strategies to enhance the sales performance. Although, this tactic is challenging if the knowledge is affirmed on unsatisfactory perceptions. Results from a study have shown that self-efficacious seller are biased upwardly and the customer-oriented salesmen are biased downwardly in their perspectives of consumer relationship quality. The influence of salesmen accuracy and inaccuracy are curvilinear and distinct, as illustrated by the response of surface analyses. The findings highlighted the benefits of evaluating the perceptions of sales men and the strategies to manage it (Mullins et al., 2014).

Two types of judgements are usually made by the sales men about consumers in face-to-face interactions, which includes the judgements that are more deliberative and intuitive. The study conducted by Hall et al. (2015) evaluated the influence of deliberative judgement and accurate intuitive on the sales men performance. A matched survey, objective, and observational survey have been obtained during, before, and after the interaction between sales man and consumer. The findings have indicated that there is an enhancement in selling performance due to the accurate intuitive judgements by enabling more suitable selling strategies. Furthermore, it has been observed that consumer orientation and listening skills influence deliberative accuracy; whereas, intuitive accuracy is influenced by empathy for the customer and domain-specific experience. Despite of the personal selling skills of sales men taught in training, effective selling requires sales men to make precise and accurate judgements about their consumers (Dixon \& Adamson, 2011). Previous researches have related the intuitive judgements to task performance and highlighted that accurate intuition can result in greater raise in salaries, higher ranks in the corporation and assist to gain higher ratings from managers (Byron et al., 2007; Hall et al. 2014).

\section{Methodology}

A questionnaire has been structured to obtain the primary data from the participants. The competencies and skills of the Saudi sellers have been identified by incorporating the questions related to the qualities of the seller, which attract the consumers to buy product or services. The questionnaire has been designed on Likert Scale. The 384 residents of Jeddah have been considered as study participants, who have been selected through random sampling approach. However, the study was restricted to Jeddah as it was difficult conduct the study in all cities of the Kingdom of Saudi Arabia due to its quite known expanse the data collected through the questionnaire was then analysed using Statistical Package of Social Sciences (SPSS) version 19.0. The reliability of questionnaire has been tested through Cronbach's alpha to assure that the developed instrument is reliable enough to produce accurate results. The descriptive statistics and the frequencies of the responses obtained through the data collection were observed; the descriptive statistics assisted to show the behaviour and qualities of seller attracts the consumer to buy a particular product or service. The frequencies of the responses have been represented in the graphical manner. From the descriptive statistics, it has been determined that the sample comprised of $48 \%$ of married individuals; however, the remaining 52\% were unmarried, as shown in Table 1.

The outcomes of Cronbach's alpha demonstrated a value of 0.873 , which is greater than $60 \%$. This has shown that the developed questionnaire is reliable to produce good results (Table 1). Moreover, table 1 has represented the mean and standard deviation of the data collected through the questionnaire. 
Table 1. Descriptive Statistics

\begin{tabular}{|c|c|c|c|}
\hline $\mathrm{SN}$ & Question & Average & $\begin{array}{l}\text { Standard } \\
\text { Deviation }\end{array}$ \\
\hline 1 & $\begin{array}{l}\text { Is the Saudi retail seller patient and work seriously and that this assists you in } \\
\text { purchasing? }\end{array}$ & 2.34 & 1.056 \\
\hline 2 & $\begin{array}{l}\text { Is the Saudi retail seller characterized by truthfulness and sincerity and that this } \\
\text { assists you in preferring to deal with him? }\end{array}$ & 2.19 & 1.000 \\
\hline 3 & $\begin{array}{l}\text { Is the male Saudi practical and less talkative characterized by honesty and } \\
\text { sincerity and that this helps you in preferring to deal with him? }\end{array}$ & 2.48 & 1.111 \\
\hline 4 & $\begin{array}{l}\text { Is the Saudi retail seller characterized by honesty and that this assists you in } \\
\text { preferring to deal with him? }\end{array}$ & 2.17 & 0.962 \\
\hline 5 & $\begin{array}{l}\text { Is the Saudi retail seller cordial, loved and less talkative and that this assists you } \\
\text { in preferring to deal with him? }\end{array}$ & 2.27 & 0.998 \\
\hline 6 & $\begin{array}{l}\text { Do the qualities of truthfulness, honesty and patience which the Saudi retail seller } \\
\text { possesses assist in the selling process? }\end{array}$ & 1.59 & 0.826 \\
\hline 7 & $\begin{array}{l}\text { Is the success of retailing shops associated to the skill of the Saudi seller working } \\
\text { at such shops? }\end{array}$ & 2.04 & 1.111 \\
\hline 8 & Does the Saudi retail seller give much attention to the time of the client? & 2.37 & 1.134 \\
\hline 9 & Do you prefer retail shops with seller who perform their duty in a good manner? & 1.37 & 0.616 \\
\hline 10 & Is supervision over the Saudi retail seller at the shops is done well? & 2.33 & 1.055 \\
\hline 11 & $\begin{array}{l}\text { Is it true that the better supervision you have over the Saudi seller, the better } \\
\text { performance you obtain? }\end{array}$ & 1.42 & 0.642 \\
\hline 12 & $\begin{array}{l}\text { Do shops that have good internal arrangement are characterized by facilities that } \\
\text { help seller to offer better service? }\end{array}$ & 1.45 & 0.714 \\
\hline 13 & $\begin{array}{l}\text { Does the good dealing of the Saudi retail seller with the consumers and meeting } \\
\text { their demands indicate he was carefully selected for the post? }\end{array}$ & 2.20 & 0.976 \\
\hline 14 & $\begin{array}{l}\text { Does the Saudi retail seller understand the desires of the consumers because this } \\
\text { reflects that he was properly trained? }\end{array}$ & 2.28 & 1.070 \\
\hline 15 & $\begin{array}{l}\text { Do successful shops are the ones that have trained manpower which understands } \\
\text { the very nature and characteristics of the product? }\end{array}$ & 1.31 & 0.569 \\
\hline \multicolumn{2}{|r|}{ Cronbach's alpha coefficient for the stability } & \multicolumn{2}{|c|}{0.873} \\
\hline
\end{tabular}

\section{Results}

With respect to age group, it has been observed from Figure 1 that the sample size of $51.2 \%$ belongs to a group of 20-30 years. It is followed by the age group that is from 30 years to less than 40 and constituted $29 \%$ of the sample size, followed by the age group that is less than 20 years with a percentage of $9.4 \%$. The age group of more than 50 years comprised only $2.6 \%$ of sample size.

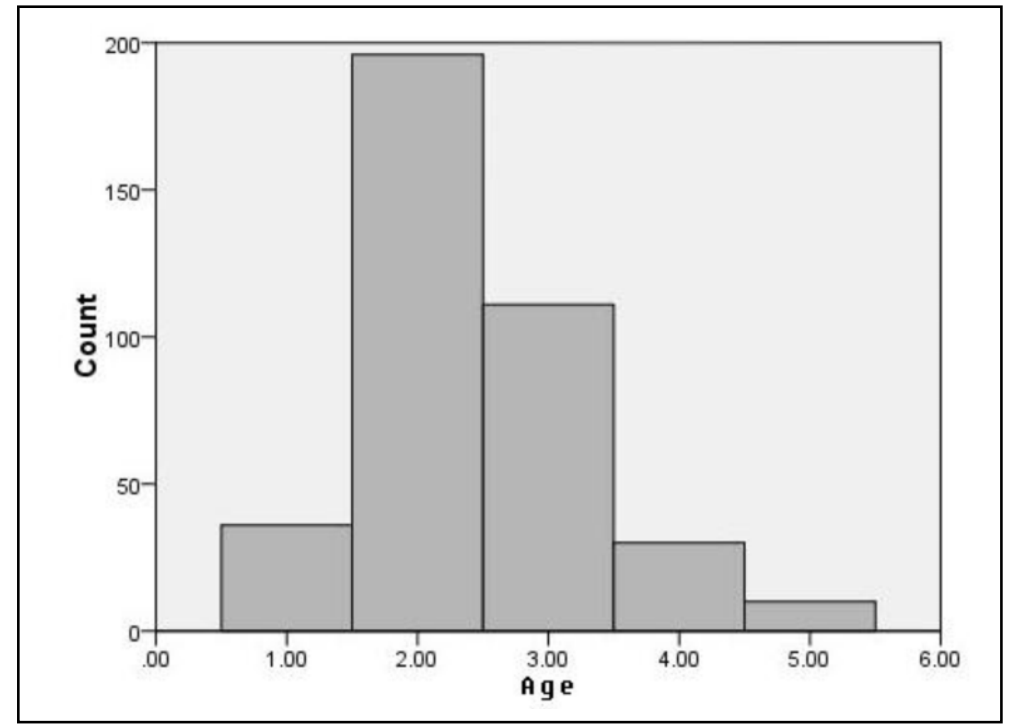

Figure 1. Age Groups

It can be observed from Figure 2 that the sample included all educational levels and qualifications. The sample size varies regarding education, in which few participants have an educational level less than university, and others are doctorates holders. The percentage of Bachelor's degree holders is $71.8 \%$ and that with an educational level less than a university one is $18.5 \%$. The percentage of those holding Master Degrees is $7.6 \%$, and those 
holding Doctorate Degrees is $2.1 \%$. This reflects the level of awareness among sample members regarding to deal with the questionnaire as virtual consumers.

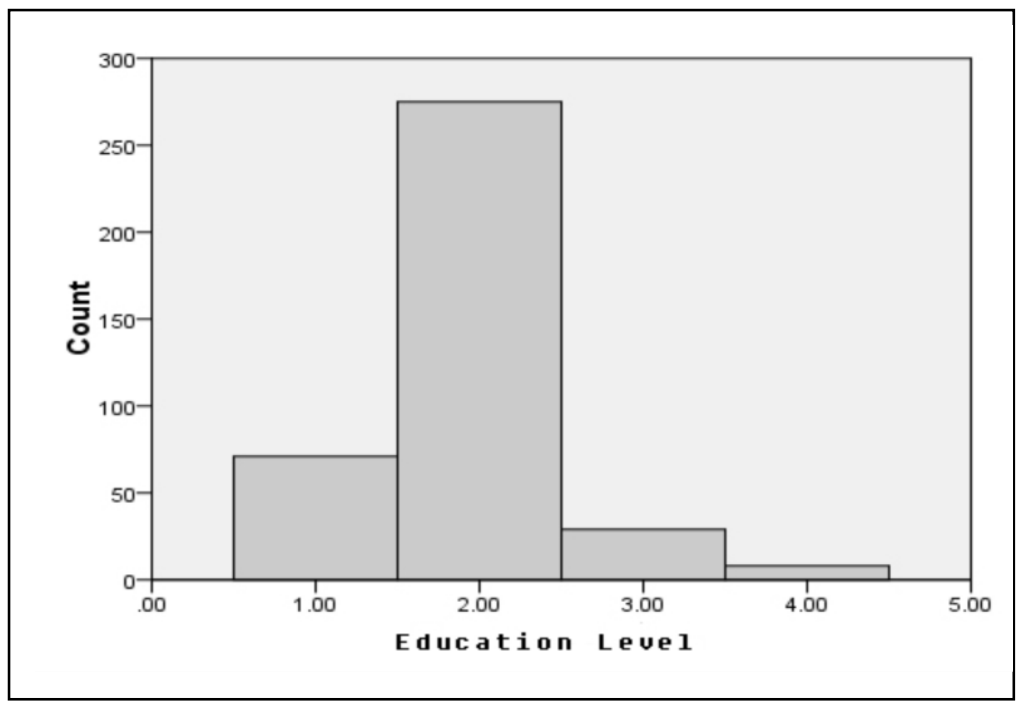

Figure 2. Educational Qualification

Taking into consideration the questions asked from respondents, it has been analyzed that the Saudi retail seller is patient and works seriously. Thus, $50.7 \%$ of respondents strongly agree that the patience level of Saudi salesman has a positive influence on their purchasing decisions. It has been observed from outcomes that $19.1 \%$ of respondents agree, $17.5 \%$ don't agree, and just $2.6 \%$ of participants don't strongly agree with the statement, as shown in Figure 3.

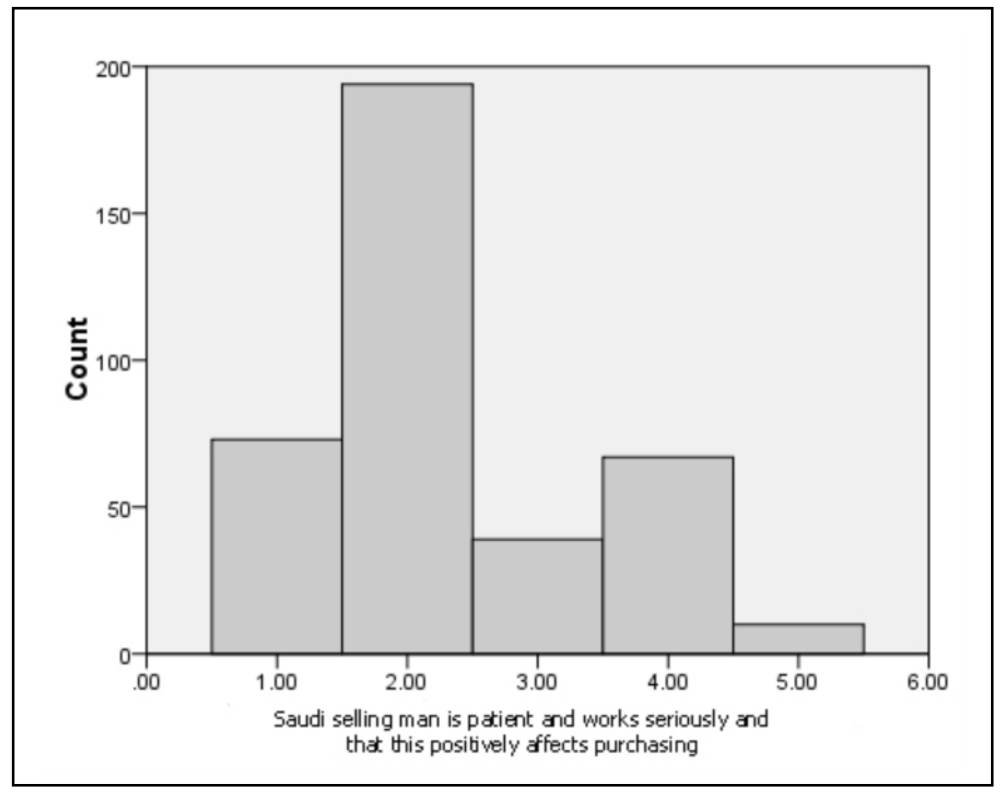

Figure 3. Patience Level of Saudi Salesman Positively affects Purchasing

When the respondents were asked about the impact of Saudi salesman characteristics to deal with customers, it has been evaluated that $45.7 \%$ of respondents agree and $25.1 \%$ strongly agree. Hence, it can be said that Saudi consumers usually prefer to deal with Saudi retail seller, because he is characterized by truthfulness and sincerity, as shown in Figure 4. 


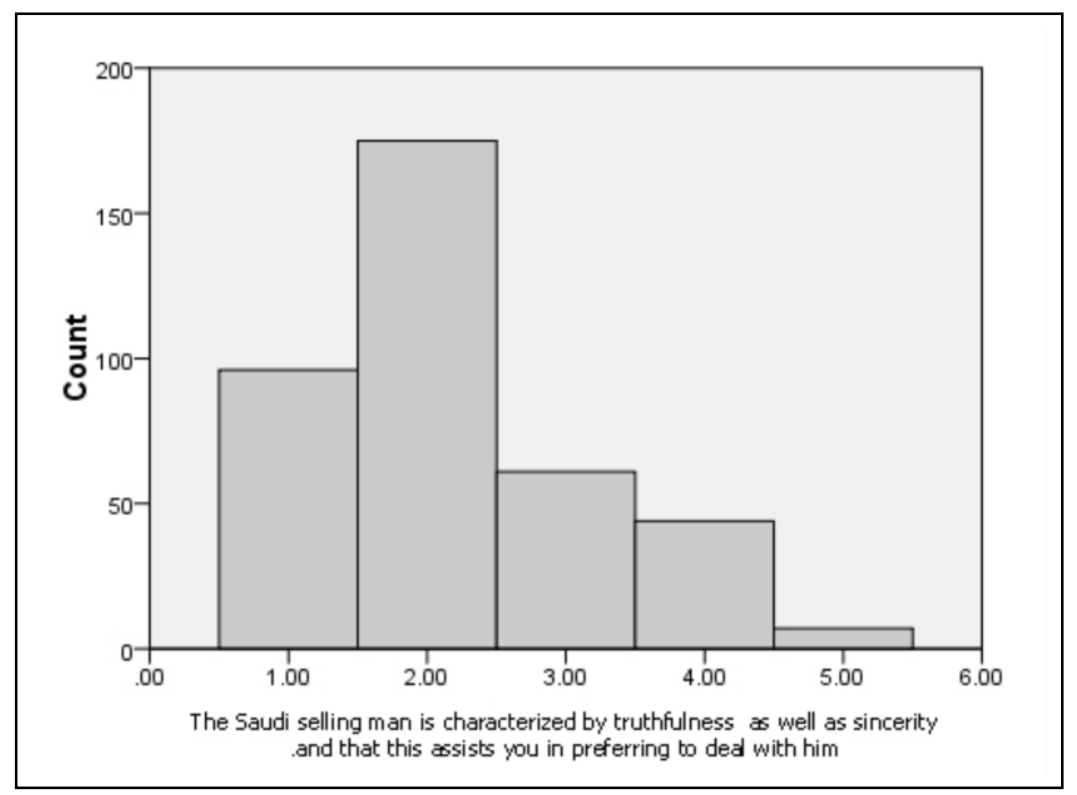

Figure 4. Characteristics of Saudi Retail seller allows Consumers to deal

With respect to less talkative nature of Saudi salesman, it has been evaluated that approximately $63 \%$ of participants respond positively. Hence, Figure 5 has shown that the consumers are likely to prefer dealing with practical and less talkative retail seller who concentrates on product rather than on mere talking.

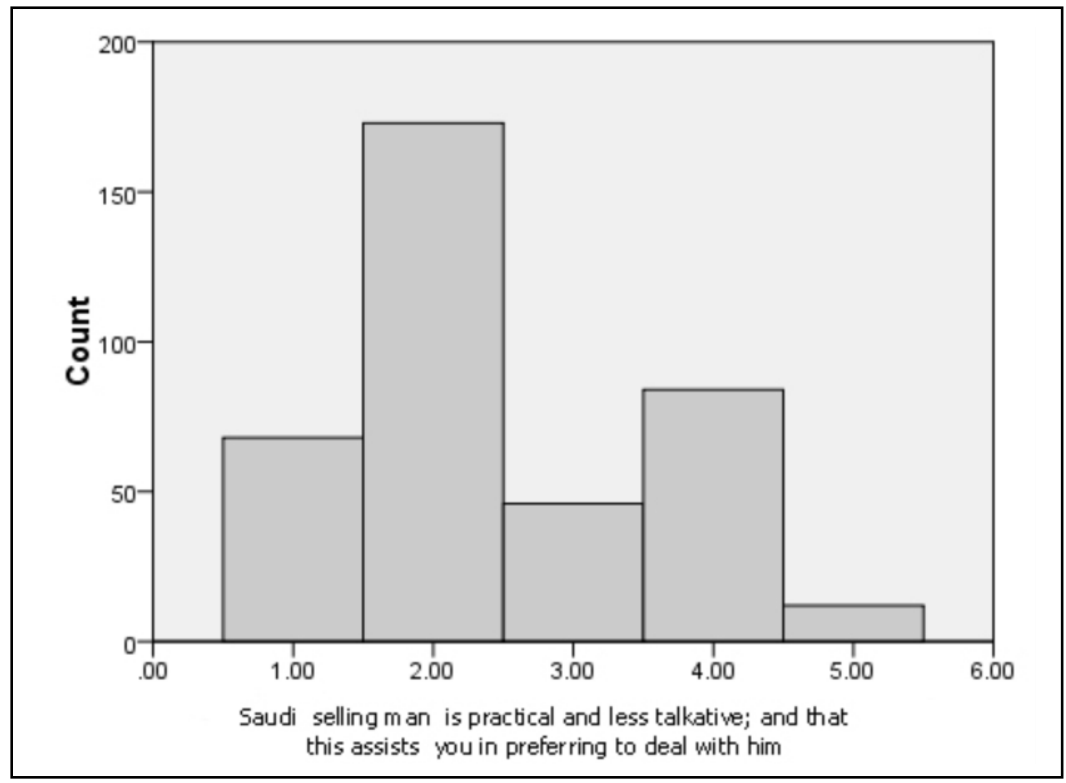

Figure 5. Consumers Prefer Dealing with Practical and Less Talkative Salesman

Taking into consideration the honesty factor of Saudi salesman, it has been observed that consumers prefer to deal with the Saudi retail seller, as shown in Figure 6. The great percentage indicates and confirms the quality of being honest from religious and cultural perspective. The Saudi society is generally characterized with honesty and this is a quality with which the Saudi retail seller is characterized over other male seller. 


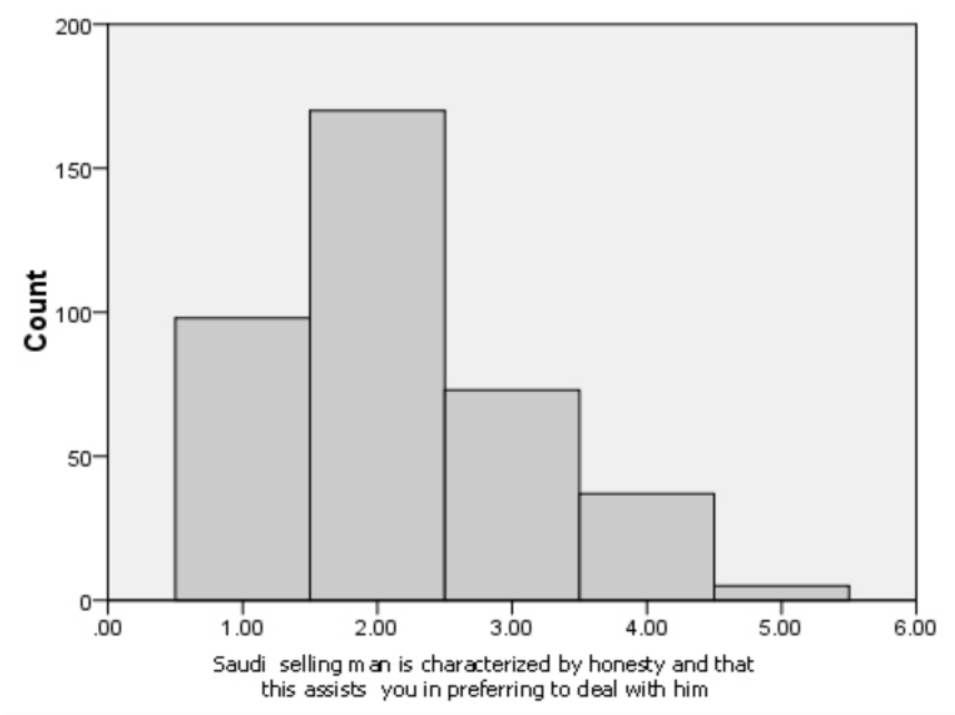

Figure 6. Honesty of Saudi Retail seller allows Consumers to Deal

Most of the respondents reported that the cordial, loving, and less talkative nature of Saudi selling males assist them to deal with him in purchasing decisions. It has been observed from Figure 7 that almost $67.1 \%$ of participants agreed with this statement. On the contrary, just $1.3 \%$ of respondents reported that they don't consider this component while making purchase decisions. With respect to the manners of Saudi retail seller, approximately $70.8 \%$ of participants respond positively that Saudi retail seller deals with them in good manner. It has been reported by participants that Saudi salesman are efficient in fulfilling the needs of customers (Figure 8). Therefore, it can be said that the selection of a suitable man leads to good results, particularly in commercial corporations or organizations that directly deals with customers.

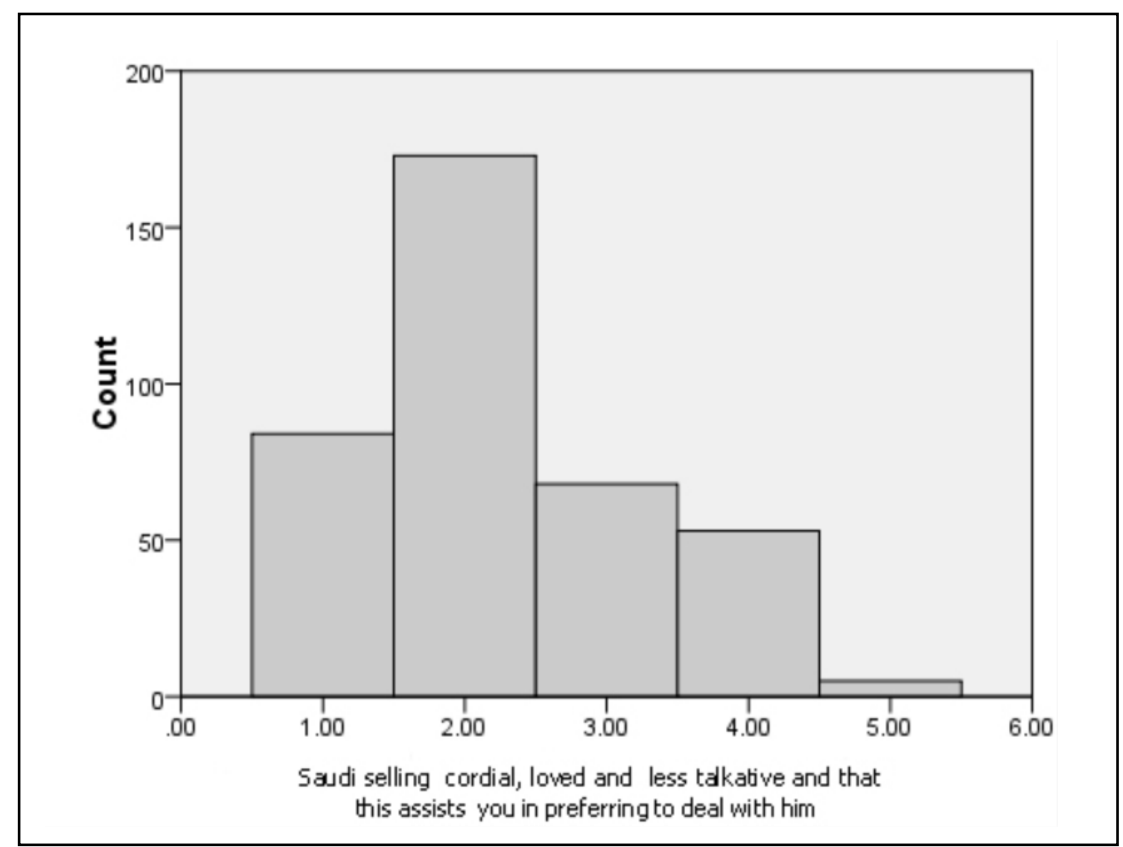

Figure 7. Consumers Prefer Dealing with Saudi Salesman due to their Cordial, Loving and Less Talkative Nature 


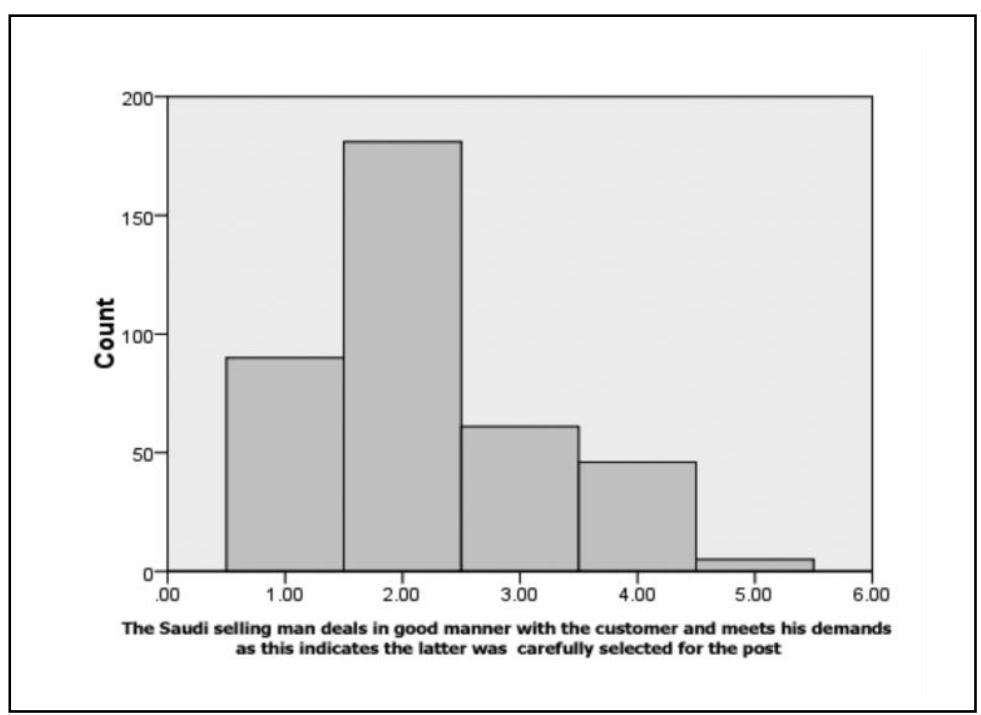

Figure 8. Saudi Retail seller Deal in Good Manner and Meet the Demands of Customers

The participants were asked about the extent to which Saudi retail seller understands their needs and desires. From the outcomes, it has been observed that $42.6 \%$ participants agreed, $24.5 \%$ strongly agree, as shown in Figure 9. Thus, it has been assessed that Saudi retailers understand the desires of its customers appropriately. This is due to a significant reason, i.e., good training provided to Saudi salesman. Undoubtedly, training is a crucial factor in success and promotion of the performance of seller at retail stores (retailers).

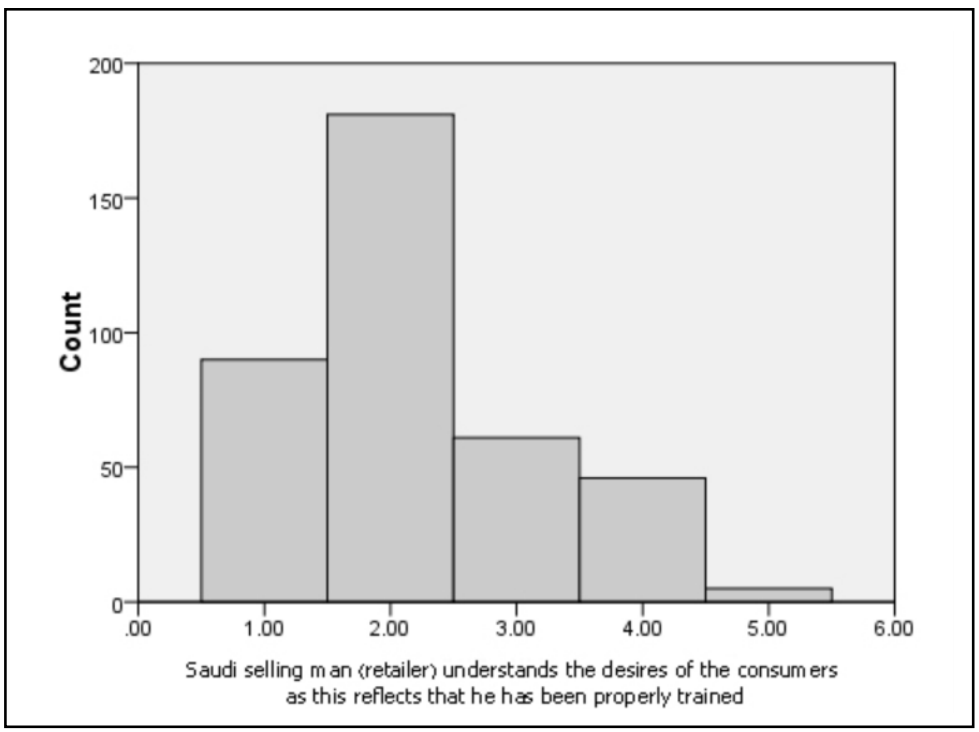

Figure 9. Proper Training enables Saudi Salesman to understand the Desires of Consumers

The collective outcomes demonstrate that the percentage of agreement is $(38.33+37.93)=76.26 \%$, which exceeds three quarters of overall responses. On the contrary, a very minor percentage of respondents $11.85 \%$ $(1.74+10.11)$ were observed to reject the statements of questionnaire. Hence, it has been determined that majority of study participants shown a positive attitude towards questionnaire. Figure 10 has demonstrated a summary of overall responses generated through research participants.

\section{Discussion and Conclusion}

To evaluate the competencies of Saudi sales man, the responses have been obtained through the analysis of data. The first priority has been given to "the successful retail shops are the ones that are manned by trained manpower that understands the nature and characteristics of the product". This reflected the training significance of manpower with respect to the product features and characteristics, because this training secures the capability of Saudi salesman to meet customers' requirements regarding a specific product. The preference of retail stores that are manned by Saudi seller, who perform their work properly, has been ranked on second number. From the 
outcomes, it has been evaluated that the performance of seller plays a significant role to retain the clients. The performance of Saudi retail seller has been found to meet the expectations of clients regarding the rendered service. Moreover, their performance is also in compliance with the Hadith of Prophet Muhammad (PBUH), which says "Allah Almighty loves that anyone does a work, he should do it perfectly". At the third rank, comes the phrase "The more supervision you have over seller, the better performance they attain". It is known that good supervision and follow-up necessarily lead to a better performance.

On fourth number, "The retail shops that have good internal arrangement and organization, the seller attached to them are characterized by offering better service" has been ranked. The good organization leads to better performance of seller and they render better service to clients. The phrase "the qualities of truthfulness, honesty and patience possessed by a retail seller (retailer) assists in the purchasing process" has been ranked on fifth number. It is appropriate to note that retail seller should possess the qualities of truthfulness, honesty and patience, ranging over relative significance, from the most significant to less significant. Finally, at rank six, came the phrase "the Saudi retail seller is a practical and less talkative official and this makes you prefer to deal with him". It has been observed that the Saudi retail seller is characterized by the fact that he is not talkative; and this promotes the serious client to deal with him.

The respondents shown a positive attitude towards questionnaire components, which helped in generating significant outcomes. With respect to social status of study participants, a relatively balanced percentage has been observed. The positive attitudes have become dominant on participants' opinions towards all variables and assumptions pertaining to significance of personal selling on consumers' attitudes. It has been recommended through outcomes that more concentration should be given while appropriately selecting the retail seller. It has been confirmed by considering the significance of particular qualities of retail seller, which comprise patience, trustfulness, serious work, and honesty.

\section{Research Limitations and Future Research}

The current study has considered the sample size from Jeddah, city of Saudi Arabia. The future studies should consider the entire Saudi Arabia as a sample of study. Moreover, future researchers should also consider other Gulf countries besides Saudi Arabia to compare the consumer requirements among places. It is also suggested that future researches should be performed by conducting cross-cultural analysis regarding competence of retail seller and its impact on the purchasing decisions of consumers. Furthermore, continuous attention must be given to developments in the field of retail selling and also to encourage the development of companies that depends on the seller, who must follow the regulations and work for the development. Specialized training courses and seminars for retail seller on specific skills such as work ethics, competency and effectiveness in work, must be conducted to secure due enhancement in the field. The usage of both modern techniques in the internal arrangement and organization of the retail shop as well as advanced electronic methods in the selling processes should be encouraged. This facilitates the task and function of the Saudi seller and the necessity of developing periodical tests for measuring the competency, performance and behavior of the sales men.

\section{Acknowledgement}

The author is very thankful to all the associated personnel in any reference that contributed in/for the purpose of this research. Further, this research holds no conflict of interest and is not funded through any source.

\section{References}

Byron, K., Terranova, S., \& Nowicki, S. (2007). Nonverbal emotion recognition and salespersons: Linking ability to perceived and actual success. Journal of Applied Social Psychology, 37(11), 2600-2619. https://doi.org/10.1111/j.1559-1816.2007.00272.x

Dietvorst, R. C., Verbeke, W. J., \& Bagozzi, R. P. (2009). Are Some Salespeople From Venus and Others From Mars? A Theory and Test of Interpersonal Mentalizing Using Functional Mri. NA-Advances in Consumer Research, 36.

Dixon, M., \& Adamson, B. (2011). The challenger sale: Taking control of the customer conversation. Penguin.

HA Bijmolt, T., KRE Huizingh, E., \& Krawczyk, A. (2014). Effects of complaint behaviour and service recovery satisfaction on consumer intentions to repurchase on the internet. Internet Research, 24(5), 608-628. https://doi.org/10.1108/IntR-03-2012-0056

Hall, Z. R., Ahearne, M., \& Sujan, H. (2015). The importance of starting right: the influence of accurate intuition on performance in salesperson-customer interactions. Journal of Marketing, 79(3), 91-109. https://doi.org/10.1509/jm.13.0505

Kotler, P., Burton, S., Deans, K., Brown, L., \& Armstrong, G. (2015). Marketing. Pearson Higher Education AU. 
Kumanduri, A., Yglesias, C., Simpson, S. J., \& Powell, J. M. (2014). Adaptive Selling.

Lilien, G. L., \& Grewal, R. eds. (2012). Handbook on business to business marketing. Edward Elgar Publishing. https://doi.org/10.4337/9781781002445

Lin, S. H. (2012). Effects of ethical sales behavior considered through transaction cost theory: To whom is the customer loyal? Journal of International Management Studies, 7(1), 31. https://doi.org/10.12816/0002265

Mullins, R. R., Ahearne, M., Lam, S. K., Hall, Z. R., \& Boichuk, J. P. (2014). Know your customer: How salesperson perceptions of customer relationship quality form and influence account profitability. Journal of Marketing, 78(6), 38-58. https://doi.org/10.1509/jm.13.0300

Ozer, L., \& Gultekin, B. (2015). Pre-and post-purchase stage in impulse buying: The role of mood and satisfaction. Journal of retailing and consumer services. https://doi.org/10.1016/j.jretconser.2014.10.004

Pettijohn, C. E., Pettijohn, L. S., \& Taylor, A. J. (2002). The influence of salesperson skill, motivation, and training on the practice of customer-oriented selling. Psychology \& Marketing, 19(9), 743-757. https://doi.org/10.1002/mar.10033

Rahman, M. N. (2012). Consumer Behavior and Retail Market Consumerism in KSA. International Journal of Scientific \& Engineering Research, 3(11).

Shavitt, S., \& Cho, H. (2016). Culture and consumer behavior: the role of horizontal and vertical cultural factors. Current Opinion in Psychology, 8, 149-154. https://doi.org/10.1016/j.copsyc.2015.11.007

Tolba, A., Seoudi, I., Meshriki, H., \& AbdelShahid, M. (2015). Impact of Ethical Sales Behavior, Quality and Image on Customer Satisfaction and Loyalty: Evidence from Retail Banking in Egypt. International Journal of Management and Marketing Research, 8(2), 1-18.

\section{Appendix}

\begin{tabular}{|c|c|c|c|c|c|}
\hline 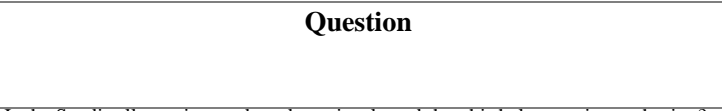 & $\begin{array}{l}\text { I strongly agree } \\
1\end{array}$ & $\begin{array}{l}\text { I agree } \\
2\end{array}$ & $\begin{array}{l}\text { I don't } \\
\text { know } \\
3\end{array}$ & $\begin{array}{l}\text { I } \\
\text { disagree } \\
4\end{array}$ & $\begin{array}{l}\text { I strongly } \\
\text { disagree } \\
5\end{array}$ \\
\hline $\begin{array}{l}\text { Is the Saudi seller patient and works seriously and that this helps you in purchasing? } \\
\text { Is the male Saudi seller characterized by truthfulness and sincerity and that this helps } \\
\text { you in preferring to deal with him? }\end{array}$ & $\begin{array}{l}73 \\
96\end{array}$ & $\begin{array}{l}194 \\
175\end{array}$ & $\begin{array}{l}39 \\
61\end{array}$ & $\begin{array}{l}67 \\
44\end{array}$ & $\begin{array}{l}10 \\
7\end{array}$ \\
\hline $\begin{array}{l}\text { Is the Saudi seller practical and less talkative and that this helps you in preferring to } \\
\text { deal with him? }\end{array}$ & 68 & 173 & 46 & 84 & 12 \\
\hline $\begin{array}{l}\text { Is the Saudi seller characterized by honesty and that this assists you in preferring to } \\
\text { deal with him? }\end{array}$ & 98 & 170 & 73 & 37 & 5 \\
\hline $\begin{array}{l}\text { Is the male Saudi cordial, loved and less talkative and that this helps you in preferring } \\
\text { to deal with him? }\end{array}$ & 84 & 173 & 68 & 53 & 5 \\
\hline $\begin{array}{l}\text { Do the qualities of truthfulness, honesty and patience which a seller possesses assist in } \\
\text { the selling process? }\end{array}$ & 221 & 118 & 27 & 15 & 2 \\
\hline $\begin{array}{l}\text { Is the success of retailing shops associated to the skill of the Saudi seller working at } \\
\text { such shops? }\end{array}$ & 158 & 114 & 60 & 41 & 10 \\
\hline Does the Saudi seller give much attention to the time of client? & 91 & 155 & 53 & 71 & 13 \\
\hline $\begin{array}{l}\text { Do you prefer the retail shops manned by Saudi seller who perform their work } \\
\text { properly }\end{array}$ & 263 & 106 & & 7 & 7 \\
\hline Does the Saudi seller working at retail shops receive proper supervision? & 91 & 142 & 93 & 46 & 11 \\
\hline Does more supervision over seller lead to better performance? & 244 & 124 & 8 & 6 & 1 \\
\hline $\begin{array}{l}\text { Do retail shops characterized by good arrangement and organization assist seller to } \\
\text { present better service }\end{array}$ & 248 & 106 & 20 & 8 & 1 \\
\hline $\begin{array}{l}\text { Does the better dealing of the Saudi seller with the customer and meeting his request } \\
\text { indicate that he was properly selected? }\end{array}$ & 90 & 181 & 61 & 46 & 5 \\
\hline $\begin{array}{l}\text { Is does the understanding of the Saudi seller for the desire of the consumer reflect that } \\
\text { he was properly trained? }\end{array}$ & 94 & 163 & 62 & 53 & 11 \\
\hline $\begin{array}{l}\text { Do the successful retail shops are the ones that that are provided with trained } \\
\text { manpower that understand the nature and characteristics of the product? }\end{array}$ & 283 & 85 & 12 & 3 & \\
\hline $\begin{array}{l}\text { Of the product? } \\
\text { Of the product? }\end{array}$ & $\begin{array}{l}2202 \\
(38.33)\end{array}$ & $\begin{array}{l}2179 \\
(37.93)\end{array}$ & $\begin{array}{l}683 \\
(11.89)\end{array}$ & $\begin{array}{l}581 \\
(10.11)\end{array}$ & $\begin{array}{l}100 \\
(1.74)\end{array}$ \\
\hline
\end{tabular}

\section{Copyrights}

Copyright for this article is retained by the author(s), with first publication rights granted to the journal.

This is an open-access article distributed under the terms and conditions of the Creative Commons Attribution license (http://creativecommons.org/licenses/by/4.0/). 